\title{
Perbedaan Pelepasan Tali Pusat Dengan Perawatan Terbuka Dan Kassa
}

\author{
Dessy Rossiani1, Regina VT Novita 2 \\ 1,2 Sekolah Tinggi Ilmu Kesehatan Sint Carolus \\ E-mail: 1regina_vita@yahoo.com,2dessy.borneo@gmail.com
}

DOI: $10.33859 /$ dksm.v11i1.541

\begin{abstract}
Abstrak
Latar Belakang: Angka kematian bayi (AKB) karena infeksi sekitar 20.5\%, salah satu penyebabnya karena perawatan tali pusat yang tidak benar. Berbagai macam perawatan tali pusat yaitu kassa betadine, kassa alkohol, kassa kering dan perawatan terbuka.

Tujuan: penelitian ini Bertujuan untuk mengetahui pengaruh perawatan tali pusat dengan kassa dan terbuka.

Metode: Desain penelitian quasi eksperimental dengan pendekatan studi komparasi, uji regresi logistik binari. Penelitian dilakukan pada bulan September 2014 sampai Januari 2015 dengan total sample yaitu 60 responden, 30 kassa dan 30 terbuka. Kriteria inklusi bayi lahir sehat, tanda vital dalam batas normal dan tidak mengalami komplikasi selama perawatan di RS.

Hasil: hasil Penelitian rata-rata pelepasan tali pusat dibawah 7 hari dengan kasaa $76.6 \%$ dan terbuka $86.73 \%$. Hasil uji regresi logistik binary dengan menilai overall fit model Ho diterima dengan hasil signifikan $>0,05$ yaitu 0,159 , Uji koefisien nagelkerke's $\mathrm{R}^{2}$ mengalami penurunan dari hasil data pertama (terbuka) 57,169, data kedua (kassa) 50,414, uji koefisien nilai t signifikan $<0,05$ yaitu nilai signifikan 0,000 . Uji statistik nilai t pada perawatan terbuka $0.000<\mathrm{P}$ value 0.05 , sedangkan dengan kassa $p$ value 0,339 . Hasil dari $\beta$ (kassa) $-0,691<\beta$ (terbuka) 1,494.

Simpulan: dari hasil penelitian dapat disimpulkan bahwa perawatan tali pusat berpengaruh terhadap lama pelepasan tali pusat. Variabel lain yang berpengaruh terhadap lama pelepasan tali pusat adalah berat badan bayi dan jenis kelamin. Usia gestasi dan jenis persalinan tidak berpengaruh terhadap lamanya pelepasan tali pusat. Kesimpulan perawatan tali pusat dengan terbuka sangat direkomendasikan untuk perawatan bayi baru lahir.
\end{abstract}

Kata kunci: Bayi baru lahir dan kassa, Perawatan tali pusat, terbuka, 
Background: The infant mortality rate (IMR) due to infection is around 20.5\%, one of the causes is due to improper umbilical cord care. Various kinds of cord care are betadine gauze, alcohol gauze, dry gauze and open treatments.

Purpose: This study aims to determine the effect of gauze and open cord care.

Methods: Quasi-experimental research design with comparative study approach, binary logistic regression test. The study was conducted from September 2014 to January 2015 with a total sample of 60 respondents, 30 kassa and 30 open. The inclusion criteria for babies were born healthy, vital signs were within normal limits and had no complications during hospitalization.

Results: The results showed that the average release of the umbilical cord was under 7 days with $76.6 \%$ gauze and $86.73 \%$ open. The results of the binary logistic regression test by assessing the overall fit of the Ho model were accepted with significant results>0.05, namely 0.159, the Nagelkerke's $R^{2}$ coefficient test decreased from the results of the first data (open) 57.169, the second data (kassa) 50.414, the coefficient test $t$ value was significant $<0.05$, which is a significant value of 0.000. The statistical test of $t$ value in open care was $0.000<P$ value 0.05, while with a gauze $p$ value was 0.339. The yield for $\beta$ (kassa) $-0.691<\beta$ (open) 1.494.

Conclusion: from the results of the study it can be concluded that umbilical cord care has an effect on the length of time to release the cord. Other variables that affect the length of time to release the umbilical cord are the baby's weight and sex. Gestational age and type of delivery have no effect on the length of time the cord is released. Conclusion Open cord care is highly recommended for the care of newborns.

Key words: newborn and gauze, umbilical cord care, open,

\section{PENDAHULUAN}

Penyebab terjadinya kematian bayi baru lahir usia 0-28 hari terbesar terdiri dari lima penyebab kematian yaitu pada pernapasan (37 persen), prematuritas (34 persen), sepsis (20,5 persen), kelainan kongenital atau bawaan (19 persen) dan pnemonia (17 persen) dalam 1.000 angka kelahiran hidup (Wijaya, 2010).

Infeksi yang terjadi pada bayi baru lahir disebabkan oleh masuknya mikroorganisme kedalam tubuh bayi karena pertahanan tubuh yang belum sempurna. Mikroorganisme tersebut dapat masuk melalui pemotongan tali pusat yang tidak steril dan kelembaban tali pusat yang memudahkan mikraoorganisme masuk kedalam tubuh bayi melalui tali pusat yang belum kering atau sembuh, (Darmadi, 2008).

Pencegahan infeksi dapat dilakukan dengan cara menjaga lingkungan sekitar bayi supaya tetap bersih, mencuci tangan menggunakan desinfektan sebelum dan sesudah menyentuh bayi, melakukan perawatan tali pusat dengan memperhatikan kebersihan dan kesterilan dalam perawatan tali pusat, pemotongan tali pusat oleh petugas kesehatan menggunakan alat yang steril (ICH, 2012).

Perawatan tali pusat dengan membiarkan tali pusat mengering, tidak ditutupi, hanya dibersihkan setiap hari 
dengan menggunakan air bersih, merupakan cara paling efektif biaya untuk perawatan tali pusat, yang sangat penting adalah tidak membubuhkan apapun pada sekitar pada sekitar daerah tali pusat karena dapat mengakibatkan infeksi (Sodikin, 2009).

Perawatan dengan menggu-nakan kassa kering lebih cepat 7,1 hari dibandingkan dengan perawatan menggunakan kompres kassa alkohol 8,8 hari dengan tanpa adanya komplikasi (Martini, 2012).

Faktor-faktor yang mempengaruhi pelepasan tali pusat antara lain infeksi, disebabkan karena tindakan atau perawatan tali pusat yang tidak bersih seperti pemotongan tali pusat tidak menggunakan alat steril ataupun setelah di potong dibubuhi dengan ramuan tradisional seperti tali pusat yang dibubuhi dengan abu, tanah, minyak, daun-daun ataupun kopi (Indriani, 2014). Infeksi yang terjadi pada bayi adalah karena masuknya mikroorganisme kedalam tubuh bayi, bakteri penyebab utamanya adalah escherrichia coli dan pada umumnya bakteri tersebut ditularkan oleh petugas kesehatan (Danuatmadja, 2008). Kelembaban tali pusat. Tali pusat tidak boleh ditutup rapat dengan apapun, karena akan membuatnya menjadi lembab. Selain memperlambat puputnya tali pusat, juga akan menimbulkan resiko infeksi (Wihono, 2009).

Perawatan tali pusat yang tidak terbuka akan lebih cepat lepas karena sirkulasi udara yang baik sehingga tali pusat dapat lepas dengan cepat dibandingkan dengan perawatan tali pusat dengan ditutup, sirkulasi udara yang tidak baik karena terhalang oleh penutup tali pusat tersebut (Wihono dan Sri,2009). Perawatan terbuka dengan lama waktu pelepasan tali pusat perawatan terbuka selama 5-6 hari, membiarkan tali pusat mengering, tidak ditutupi, hanya dibersihkan setiap hari dengan menggunakan air bersih (Wihono dan Sri,2009).

Perawatan tali pusat yang menggunakan kassa steril memiliki lama pelepasan normal (antara 5-7 hari). Perawatan tali pusat menggunakan kassa steril lebih cepat puput, karena kassa steril memiliki serat yang longgar sehingga mudah dilalui udara. Udara membantu mempercepat proses pelepasan tali pusat. Sedangkan jika menggunakan alkohol 70\%, terjadi penyerapan bahan tersebut pada tali pusat dan menyebabkan tali pusat lembab dan basah. Jika tali pusat basah, tali pusat lebih mudah ditempati bakteri dan dapat meningkatkan terjadinya resiko infeksi sehingga berpengaruh pada lama pelepasan tali pusat (Yuswoyani \& Ratnasari, 2010).

Perawatan dengan meng-gunakan kompres kassa alkohol pelepasan tali pusat yakni 8.8 hari, Masyarakat menganggap bahwa perawatan tali pusat menggunakan kassa alkohol lebih efektif karena dianggap itu sebagai obat dan dapat mengurangi bau 
pada tali pusat selain itu juga karena informasi yang mereka dapat dari petugas kesehatan yang membantu proses persalinan mereka, menganjurkan perawatan dengan kassa alkohol (Martini, 2012).

Perawatan tali pusat pada bayi dan hasil penelitian yang telah banyak dilakukan dalam upaya mencegah terjadinya infeksi dan kematian pada bayi dengan mempercepat pelepasan tali pusat ada beberapa cara yang dapat digunakan untuk perawatan tali pusat antara lain perawatan menggunakan kassa alkohol, kassa betadhine, ASI, perawatan kering, air steril dan pewarnaan triple dimana dari hasil penelitian tersebut perawatan tali pusat terbuka merupakan yang paling baik (Whitmore, 2010).

Mayoritas Rumah Sakit Ibu dan Anak (RSIA) di Jakarta pusat melakukan perawatan tali pusat menggunakan kassa kering. Perawatan tali pusat yang pernah dilakukan di RSIA "E” dengan berbagai cara antara lain dengan menggunakan kassa bethadine, kassa alkohol dan saat ini melakukan perawatan tali pusat menggunakan kassa steril. Data yang didapat dari data pasien yang kontrol bayi baru lahir dari 100 bayi yang kontrol ada sekitar 5 bayi yang mengalami infeksi pada tali pusat seperti tali pusat berbau dan basah terjadinya infeksi dan cara perawatan tali pusat tersebut tidak diketahui. Peneliti tertarik untuk melakukan penelitian tentang perbedaan antara perawatan tali pusat menggunakan kassa dan terbuka, yang dipengaruhi oleh usia gestasi, berat badan bayi, jenis kelamin, dan jenis persalinan. Hasil penelitian dapat berkontribusi terhadap penurunan angka infeksi pada bayi baru lahir.

\section{METODE}

Pada penelitian ini, menggunakan desain penelitian quasi eksperimental dengan pendekatan studi komparasi. Uji statistic yang digunakan adalah uji regresi logistik binari dengan melihat:

a. Overall fit model nilai signifikan > 0,05, maka uji statistik layak digunakan.

b. Uji keseluruhan model digunakan apakah Ho dapat diterima dengan melihat keseluruhan data, dengan memperhatikan nilai -2 $\log$ likehood, apakah hasil mengalami penurunan dari block 0 (perlakuan 1) ke block 1 (perlakuan 2), jika mengalami penurunan maka Ho dapat diterima.

c. Uji koefisien nagelkerke's $\mathrm{R}^{2}$ menunjukan nilai variabilitas dan variabel dependent $Y$ (perawatan tali pusat) yang dapat dijelaskan oleh variabilitas variabelvariabel bebas X (lama pelepasan).

d. Uji koefisien nilai $t$ dengan memperhatikan pada data pertama dan kedua apakah signifikan jika hasil $<0,05$ maka data signifikan.

e. Uji pengaruh dengan memperhatikan nilai $\beta$ (beta) mendekati 1,0 maka variabel independent tidak mempengaruhi dan 
sebaliknya jika $\beta$ (beta) menjauh dari 1,0 maka variabel independent (X) mempengaruhi variabel dependent $\mathrm{Y}$ (perawatan tali pusat).

Penelitian dilakukan pada bulan September 2014 sampai Januari 2015 dengan total sample yaitu 60 responden, 30 kassa dan 30 terbuka. Kriteria inklusi bayi lahir sehat, tanda vital dalam batas normal dan tidak mengalami komplikasi selama perawatan di Rumah Sakit.

\section{HASIL PEMBAHASAN}

\section{A. Analisis univariat}

Hasil analisis univariat menggambarkan karakteristik responden berdasarkan jenis kelamin, lama pelepasan tali pusat, berat badan bayi baru lahir, usia kehamilan ibu dan proses persalinan.

Tabel 1 Distribusi frekuensi responden berdasarkan jenis kelamin perawatan tali pusat bayi

\begin{tabular}{ccccc}
\hline \multirow{2}{*}{$\begin{array}{c}\text { Jenis } \\
\text { kelamin } \\
\text { bayi }\end{array}$} & \multicolumn{2}{c}{ Kassa } & \multicolumn{2}{c}{ Terbuka } \\
\cline { 2 - 5 } & Jumlah & $\%$ & Jumlah & $\%$ \\
\hline Perempuan & 10 & 33.3 & 11 & 36.7 \\
\hline laki-laki & 20 & 66.7 & 19 & 63.3 \\
\hline Total & 30 & 100.0 & 30 & 100.0 \\
\hline
\end{tabular}

Distribusi responden berdasarkan jenis kelamin laki-laki terdapat 20 responden $(66,7 \%)$ pada perawatan dengan kassa dan 19 responden $(63.3 \%)$ pada perawatan tali pusat dengan terbuka.
Tabel 2 Distribusi frekuensi responden berdasarkan lama hari pelapasan tali pusat bayi

\begin{tabular}{ccccc}
\hline $\begin{array}{c}\text { Lama } \\
\text { hari } \\
\text { pelepasan } \\
\text { tali pusat }\end{array}$ & \multicolumn{2}{c}{ Kassa } & \multicolumn{2}{c}{ Terbuka } \\
\cline { 2 - 5 } 3 hari & 0 & 0 & $\mathrm{~N}$ & $\%$ \\
4 hari & 1 & 3.3 & 0 & 0 \\
5 hari & 3 & 10.0 & 6 & 20 \\
6 hari & 10 & 33.3 & 11 & 36.7 \\
7 hari & 8 & 26.7 & 8 & 26.7 \\
8 hari & 4 & 13.3 & 1 & 3.3 \\
9 hari & 1 & 3.3 & 0 & 0 \\
$>9$ hari & 3 & 10.0 & 3 & 10.0 \\
Total & 30 & 100.0 & 30 & 100.0 \\
\hline
\end{tabular}

Distribusi responden berdasarkan lama pelepasan tali pusat tercepat terdapat pada hari ke 3 pada perawatan terbuka sebanyai 1 responden $(3.3 \%)$, sedangkan pada perawatan menggunakan kassa tercepat pada hari ke 4 terdapat 1 respondan $(3,3 \%)$. Tali pusat lepas pada hari ke enam perawatan menggunakan kassa dan terbuka tidak jauh berbeda jumlah responden yaitu 10 responden $(33,3 \%)$ perawatan tali pusat dengan kassa, 11 responden $(36,7 \%)$ perawatan terbuka.

Tabel 3 Distribusi frekuensi responden berdasarkan lama lepas tali pusat tali pusat bayi

\begin{tabular}{ccccc}
\hline $\begin{array}{c}\text { Lama } \\
\text { lepas tali } \\
\text { pusat }\end{array}$ & \multicolumn{2}{c}{ Kassa } & \multicolumn{2}{l}{ Terbuka } \\
\hline & $\mathrm{N}$ & $\%$ & $\mathrm{n}$ & $\%$ \\
\hline$>7$ hari & 7 & 23.3 & 4 & 13.3 \\
$\leq 7$ hari & 23 & 76.6 & 26 & 86.7 \\
Total & 30 & 100.0 & 30 & 100.0 \\
\hline
\end{tabular}

Distribusi responden berdasarkan lama lepasan tali pusat pada $\leq 7$ hari terdapat 23 responden $(76,6 \%)$ pada perawatan tali pusat dengan kassa, perawataan tali pusat terbuka terdapat 26 responden $(86,7 \%)$ perawataan tali pusat terbuka. Lepas tali pusat $>7$ hari 
terdapat 7 responden $(23,3 \%)$ pada perawatan dengan kassa, 4 responden $(13,3$ $\%)$ pada perawatan tali pusat terbuka.

Tabel 4 Distribusi frekuensi responden berdasarkan berat badan bayi baru lahir

\begin{tabular}{ccccc}
\hline $\begin{array}{c}\text { Berat } \\
\text { badan bayi } \\
\text { baru lahir }\end{array}$ & \multicolumn{2}{c}{ Kassa } & $\%$ & \multicolumn{2}{c}{ Terbuka } \\
\hline$\leq 2500$ & 2 & 6.7 & 4 & 13.3 \\
\hline$>2500$ & 28 & 93.3 & 26 & 86.7 \\
\hline Total & 30 & 100.0 & 30 & 100.0 \\
\hline
\end{tabular}

Disribusi frekuensi responden berdasarkan berat badan > $2500 \mathrm{gr}$ hampir sama antara perawatan dengan kassa dan terbuka. Perawatan dengan kassa 28 responden $(93.3$ $\%)$, perawatan terbuka 26 responden $(86.7$ $\%)$. Berat badan bayi $\leq 2500$ gr terdapat 2 responden $(6.7 \%)$ perawatan tali pusat menggunakan kassa, 4 responden $(13.3 \%)$ pada perawatan tali pusat terbuka.

Tabel 5 Distribusi responden berdasarkan usia kehamilan

\begin{tabular}{ccccc}
\hline $\begin{array}{c}\text { Lama } \\
\text { kehamilan }\end{array}$ & \multicolumn{2}{c}{ Kassa } & \multicolumn{2}{c}{ Terbuka } \\
\hline$>37 \mathrm{mgg}$ & 27 & 90.0 & 29 & 96.7 \\
$\leq 37 \mathrm{mgg}$ & 3 & 10.0 & 1 & 1.1 \\
Total & 30 & 100.0 & 30 & 100.0 \\
\hline
\end{tabular}

Distribusi frekuensi responden berdasarkan usia kehamilan >37 minggu terdapat 27 responden $(90.0 \%)$ perawatan tali pusat menggunakan kassa dan 29 responden (96.7 $\%)$ pada perawatan tali pusat terbuka. Usia kehamilan ibu pada $\leq 37$ minggu terdapat 3 responden $(10.0 \%)$ perawatan dengan kassa dan 1 responden $(1.1 \%)$ pada perawatan dengan terbuka.

\begin{tabular}{ccccc} 
Tabel & 6 & \multicolumn{2}{c}{$\begin{array}{c}\text { Distribusi } \\
\text { berdasarkan jenis persalinan }\end{array}$} & \multicolumn{2}{c}{ frekuensi } & responden \\
\hline $\begin{array}{c}\text { Jenis } \\
\text { persalinan }\end{array}$ & \multicolumn{2}{c}{ Kassa } & \multicolumn{2}{c}{ Terbuka } \\
\cline { 2 - 5 } & $\mathrm{n}$ & $\%$ & $\mathrm{n}$ & $\%$ \\
\hline Pervaginam & 9 & 30.0 & 8 & 26.7 \\
SC & 21 & 70.0 & 22 & 73.3 \\
Total & 30 & 100.0 & 30 & 100.0 \\
\hline
\end{tabular}

Distribusi frekuensi responden berdasarkan jenis persalinan pada persalinan SC dengan indikasi dapat 21 responden $(70.0 \%)$ pada perawatan dengan kassa dan 22 responden (73.3 \%) pada perawatan dengan terbuka. Jenis persalinan pervaginam sebanyak 9 responden $(30.0 \%)$ pada perawatan dengan kassa dan 8 responden (26.7\%) pada perawatan dengan terbuka.

\section{B. Bivariat}

Pada bivariat peneliti menggunakan uji regresi logistik binary dengan menilai overall fit model Ho diterima dalam penelitian dengan hasil signifikan >0,05 yaitu 0,159, Uji koefisien nagelkerke's $\mathrm{R}^{2}$ mengalami penurunan dari hasil data pertama (terbuka) 57,169, data kedua (kassa) 50,414, uji koefisien nilai $\mathrm{t}$ signifikan $<0,05$ yaitu nilai signifikan 0,000 .

Tabel 7 Uji koefisien regresi logistik (uji nilai t)

\begin{tabular}{cccc}
\hline \multirow{3}{*}{ Terbuka } & Constant & B & Sig \\
\cline { 3 - 4 } Kassa & & & \\
& & & \\
& Perawatantalipusat & -.691 & .339 \\
& Beratbadanbayi & -.001 & .254 \\
& Usiakehamilanibu & 19.50 & .999 \\
& Jeniskelamin & -.997 & .244 \\
& Prosespersalinan & .281 & .953 \\
Constant & 6.257 & 3.561 \\
\hline
\end{tabular}


Pengaruh lama pelepasan terhadap perawatan tali pusat. Berdasarkan uji statistik nilai $\mathrm{t}$ ( $\mathrm{p}$ value/sig) pada perawatan terbuka $0,000<0,05$ berarti Ho diterima, sedangkan pada perawatan dengan kassa ( $\mathrm{p}$ value/ sig) 0,339 > 0,05 Ho ditolak. Pembuktian pengaruh lama pelepasan pada perawatan terbuka terhadap parawatan tali pusat menggunakan kassa dengan melihat hasil dari $\beta$ (kassa) $-0,691<\beta$ (terbuka) 1,494. Karena perawatan dengan kassa $\beta$ menjauh dari 1,0 maka perawatan tali pusat berpengaruh terhadap lama pelepasan tali pusat. Hal ini sesuai dengan penelitian Hidayat (2008) dimana perawatan tali pusat menggunakan kassa steril yaitu mempertahankan sisa tali pusat dalam keadaan terbuka agar terkena udara dan tutupi dengan kain bersih secara longgar, lipat popok dibawah sisa tali pusat, jika tali pusat terkena kotoran feces, cuci dengan sabun dan air bersih kemudian keringkan sehingga mudah lepas tanpa adanya infeksi. Penelitian ini didukung juga melalui perawatan tali pusat terbuka adalah membiarkan tali pusat mengering, tidak di tutup hanya membersihkan dengan air bersih setiap hari, setiap kali tali pusat basah dan kotor untuk mencegah infeksi, perawatan tali pusat dengan cara terbuka dengan tidak menutupi apapun disekitar tali pusat merupakan cara yang yang dapat mencegah tibulnya infeksi yang disebabkan karena sirkulasi udara disekitar tali pusat yang lembab (Sodikin, 2009). Tali pusat perlu dirawat dengan benar sehingga mempercepat lepasnya tali pusat.

Pengaruh lama pelepasan tali pusat terhadap berat badan bayi. Berdasarkan uji statistik nilai $\mathrm{t}$ ( $\mathrm{p}$ value/sig) pada perawatan terbuka $0,000<0,05$ berarti Ho diterima, sedangkan pada perawatan dengan kassa terhadap berat badan ( $\mathrm{p}$ value/ sig) 0,254 > 0,05 Ho ditolak. Pembuktian pengaruh lama pelepasan pada perawatan terbuka terhadap parawatan tali pusat menggunakan kassa dengan melihat hasil dari $\beta$ (kassa) $-0,001<$ $\beta$ (terbuka) 1,494. Karena perawatan dengan kassa $\beta$ menjauh dari 1,0 maka berat badan bayi pada perawatan tali pusat dengan kassa berpengaruh terhadap lama pelepasan tali pusat. Jadi, apabila bayi dengan berat badan $\leq 2500$ gram dirawat menggunakan kassa akan lama lepas tali pusatnya. Hasil ini didukung oleh Lestari (2013) dimana Berat badan bayi merupakan salah satu faktor yang mempengaruhi pelepasan tali pusat, bayi yang prematur rentan dengan infeksi tali pusat dikarenakan imunitas yang belum sempurna.

Pengaruh lama pelepasan tali pusat terhadap usia kehamilan ibu. Berdasarkan uji statistik nilai $\mathrm{t}$ ( $\mathrm{p}$ value/sig) pada perawatan terbuka $0,000<0,05$ berarti Ho diterima, sedangkan pada perawatan dengan kassa ( $\mathrm{p}$ value/ sig) $0,999>0,05$ Ho ditolak. Pembuktian pengaruh lama pelepasan pada perawatan terbuka terhadap usia kehamilan 
ibu pada perawatan tali pusat menggunakan kassa dengan melihat hasil dari $\beta$ (kassa) $19,509>\beta$ (terbuka) 1,494. Karena perawatan dengan kassa $\beta$ mendekat dari 1,0 maka usia kehamilan ibu pada perawatan tali pusat menggunakan kassa tidak berpengaruh terhadap lama pelepasan tali pusat. Hal ini bertentangan dengan Muthoovaloo (2014) dimana bayi lahir kurang bulan mempunyai organ tubuh yang belum berfungsi normal untuk bertahan hidup di luar rahim. Semakin muda umur kehamilan, fungsi organ tubuh semakin kurang sempurna dan prognosisnya semakin kurang baik. Kelompok BBLR ini sering mendapat penyulit atau komplikasi akibat kurang matangnya organ karena masa gestasi yang kurang (premature).

Pengaruh lama pelepasan tali pusat terhadap jenis kelamin. Berdasarkan uji statistik nilai t ( $\mathrm{p}$ value/sig) pada perawatan terbuka $0,000<0,05$ berarti Ho diterima, sedangkan pada perawatan dengan kassa ( $p$ value/ sig) 0,244 > 0,05 Ho ditolak. Pembuktian pengaruh lama pelepasan pada perawatan terbuka terhadap jenis kelamin pada perawatan tali pusat menggunakan kassa dengan melihat hasil dari $\beta$ (kassa) $0,997>\beta$ (terbuka) 1,494. Karena perawatan dengan kassa $\beta$ menjauh dari 1,0 maka jenis kelamin pada perawatan tali pusat menggunakan kassa berpengaruh terhadap lama pelepasan tali pusat. Jadi, apabila bayi berjenis kelamin laki-laki dirawat dengan menggunakan kassa tali pusatnya akan mempengaruhi lepasnya tali pusat, karena menurut Sari (2010), bayi laki-laki lebih rentan terhadap infeksi $4 \mathrm{x}$ lebih sering dibandingkan bayi perempuan.

Pengaruh lama pelepasan tali pusat terhadap jenis persalinan. Berdasarkan uji statistik nilai $\mathrm{t}$ ( $\mathrm{p}$ value/sig) pada perawatan terbuka $0,000<0,05$ berarti Ho diterima, sedangkan pada jenis kelamin (p value/ sig) 0,953>0,05 Ho ditolak. Pembuktian pengaruh lama pelepasan pada perawatan terbuka terhadap jenis persalinan pada perawatan tali pusat menggunakan kassa dengan melihat hasil dari $\beta$ (kassa) $0,281<\beta$ (terbuka) 1,494. Karena perawatan dengan kassa $\beta$ mendekat dari 1,0 maka jenis persalinan pada perawatan tali pusat menggunakan kassa berpengaruh terhadap lama pelepasan tali pusat. Hal ini dapat terjadi karena faktor infeksi dari internal yaitu tubuh bayi sendiri dan eksternal dari lingkungan. Tali pusat tidak boleh ditutup rapat dengan apapun, karena akan membuatnya menjadi lembab. Selain memperlambat puputnya tali pusat, juga akan menimbulkan resiko infeksi (Wihono, 2009).

Kondisi sanitasi lingkungan daerah sekitar bayi baru lahir yang tidak bersih dapat mengakibatkan mudahnya masuk mikroorganisme melalui luka pemotongan tali pusat karena tindakan perawatan tali yang tidak memperhatikan kebersihan dan 
kesterilan lingkungan sekitar bayi baru lahir (Martini, 2012).

\section{SARAN}

Hasil penelitian ini diharapkan perawat dapat mempelajari dan mengetahui bahwa dalam pelepasan tali pusat terdapat perbedaan lama pelepasan antara perawatan tali pusat menggunakan kassa dan terbuka. Diharapkan perawat memperhatikan dan mengetahui pengaruh lama pelepasan tali pusat. Dengan perawatan terbuka maka pelepasan tali pusat akan cepat dan bayi terhindar dari infeksi.

\section{DAFTAR PUSTAKA}

Danuatmaja. (2008). Persalinan Normal Tanpa Rasa Sakit. Jakarta: Puspaswara.

Darmadi. (2008). Infeksi Nosokomial. Jakarta: Salemba Medika.

Hidayat, A. A. (2008). Asuhan Neonatus, Bayi dan Balita: Buku Praktikum Kebidanan. Jakarta: EGC.

(ICH), I. H. (2012). Pencegahan Infeksi Bayi Baru Lahir. Dipetik agustus senin, 2014, dari http://www.ichrc.org/34pencegahan-infeksi-bayi-baru-lahir

Indiarni, S. (2014). Perawatan Tali Pusat. Dipetik Agustus Kamis, 2014, dari http://sisriindrianiicy.wordpress.com/c ategory/uncategorized/
Lestari, Handayani Indah. (2013). Asuhan kenidanan pada bayi umur 6 jam dengan penatalaksanaan perawatan tali pusat pada bayi Ny. R di BPS Nurhasanah teluk betung bandar lampung tahun 2013, diakses di Http://handayaniakbidadilaangkatanv. com/2013/07/asuhan-kebidanan-padabayi-umur-6-jam_24.html

Martini, D. E. (2012). Perbedaan Lama Pelepasan Tali Pusat Bayi Baru Lahir Yang Mendapatkan Perawatan Menggunakan Kassa Keringdan Kompres Alkohol Di Desa Plosowahyu Kabupaten Lamongan. Dipetik Juni Rabu, 2014, dari http://stikesmuhla.ac.id/v2/wpcontent/uploads/jirnalsurya/noXIII/7.p df

Muthoovaloo, vaisnavi. (2014). Faktorfaktor yang mempengaruhi berat badan lahir bayi. Dipetik februari jumat, 2015, dari http:// www.academia.edu/8825619/

faktorfaktor_yang_mempengaruhi_ber at_badan_lahir_bayi_vaisnavi_muthoo valoo_nim_102011430_a9

Sari, ira mulya. (2010). Faktor - faktor risiko prenatal dan neonatal yang berhubungan dengan kejadian infeksi tali pusat di ruang neonatus risiko tinggi irna d anak rsup dr. M. Djamil padang tahun 2010. Dipetik februari, jumat, 2015, dari http://repository.unand.ac.id/18330/1/ FAKTOR\%20\%20FAKTOR\%20RISIKO\%20PREN ATAL\%20DAN\%20NEONATAL\%2 OYANG\%20BERHUBUNGAN\%20D ENGAN\%20KEJADIAN\%20INFEK SI\%20\%20TALI\%20PUSAT.pdf

Sodikin. (2009). Buku Saku Keperawatan Tali Pusat. Jakarta: EGC. 
Dinamika Kesehatan Jurnal Kebidanan dan Keperawatan Vol 11 No. 1 Juli 2020 ( ISSN: 2086-3454 EISSN: 2549-4058)

url: http://ojs.dinamikakesehatan.unism.ac.id DOI : https://doi.org/10.33859/dksm.v11i1

Perbedaan Pelepasan Tali Pusat Dengan Perawatan Terbuka Dan Kassa

Whitmore, J. M. (2010). 1-1-2010. Newborn

Umbilical Cord Care:An Evidence

Basedquality Improvement.

Wijaya, A. M. (2010). kondisi angka kematian neonatal (AKN), angka kematian bayi $(A K B)$, angka kematian balita (AKBAL), angka kematian ibu (AKI) dan penyebabnya di indonesia. Dipetik Jul i kamis , 2014, dari file://C:/Users/AC ER/Downloads/MDGs/infodokterku.c om\%20-\%20infodokterku.com.html 